\title{
PENERAPAN PRINSIP SYARIAH DALAM PRAKTIK PERJANJIAN WARALABA SYARIAH
}

\section{Sudaryat}

Fakultas Hukum Universitas Padjadjaran

sudaryatpermana@gmail.com

\begin{abstract}
ABSTRAK
Franchise berkerbang tidak hanya yang konvensional namun juga yang syariah tidak terkecuali dengan Indonesia. waralaba ditetapkan alam Undang-Undang No.20 Tahun 2008 sebagai salah satu pola kemintraan yang menjadi salah satu sarana pemberdayaan usaha mikro, usaha kecil dan usaha menengah. Waralaba yang berkembang di Indonesia tidak hanya waralaba konvensional tetapi berkembang pula waralaba berdasarkan system syariah. Waralaba berdasarkan system syariah merupakan memiliki kemiripan dengan syirkah yaitu syirkah mudharabah.

Banyaknya waralaba yang mengklaim menerapkan prinsip syariah tentu membutuhkan peran pengawas sehingga prinsip syariah yang diterapkan benar-benar prinsip syariah yang bersumber dari Al Quran, Hadist dan ljtihad. Selama ini usaha-usaha yang mengklaim menggunakan prinsip syariah, pengawasannya dilakukan oleh Majelis Ulama Indonesia melalui salah satu lembaganya yaitu Dewan Pengawas Syariah. Begitu juga dengan usaha waralaba yang berdasarkan system syariah, perlu ada pengawasan dari Dewan Pengawas Syariah sehingga prinsip-prinsip syariah yang diterapkan benar-benar prinsip syariah sebagaimana yang ada dalam tuntutan Al Quran, Hadits dan ljtihad.
\end{abstract}

\section{Pendahuluan}

Istilah franchise yang dikenal sekarang lahir di Amerika Serikat kurang lebih satu abad yang lalu ketika perusahaan mesin jahit Singer mulai memperkenalkankonsepfranchisesebagaisuatucarauntukmengembangkan distribusi produknya. Demikian pula perusahaan-perusahaan bir memberikan lisensi kepada perusahaan kecil sebagai upaya mendistribusikan produk 
mereka. Pada saat itu, di Amerika Serikat timbul apa yang dinamakan sistem waralaba generasi pertama yang disebut straight product franchising (waralaba produksi murni). Pada mulanya, sistem ini berupa pemberian lisensi bagi penggunaan nama pada industri minuman dengan merek coca cola, kemudian berkembang sebagai sistem pemasaran pada industri mobil dalam hal ini General Motor. Kemudian sistem franchise ini dikembangkan oleh produsen bahan bakar, yang memberikan hak pemberi waralaba kepada pemilik pompa bensin sehingga terbentuk jaringan penyediaan untuk memenuhi sumplai bahan bakar dengan cepat. ${ }^{1}$ Di samping istilah franchise atau franchising, istilah untuk para pihak dalam franchise yaitu franchisor $^{2}$ dan franchisee. ${ }^{3}$

Saat ini menurut Bill Nickels, Jim Mc Hugh and Susan Mc Hugh waralaba atau franchise telah memasuki setiap aspek dari kehidupan orang Amerika dan bisnis global dengan menawarkan produk dan jasa yang handal, praktis, dan dengan harga yang kompetitif. Pertumbuhan waralaba di seluruh dunia tentu tidak tercapai secara tidak sengaja. Sekitar sepuluh juta orang di Amerika Serikat bekerja dalam waralaba. Bisnis yang diwaralabakan bernilai 1,5 triliun dollar Amerika Serikat atau 10\% dari produk domestik bruto Amerika Serikat. ${ }^{4}$ Angka ini cukup signifikant di Amerika Serikat sebagai negara maju dan negara adidaya.

Di Indonesia menurut Adrian Sutedi, waralaba mulai dikenal pada tahun 1950-an dengan munculnya dealer kendaraan bermotor melalui pembelian lisensi atau menjadi agen tunggal pemilik merek. Waralaba di Indonesia mulai berkembang ketika masuknya waralaba asing pada tahun 80-90an. KFC, Mc Donald's, Burger King dan Wendys adalah sebagian dari jejaring waralaba asing yang masuk ke Indonesia pada awal-awal berkembangnya waralaba di Indonesia. Selain waralaba asing, waralaba lokal pun mulai berkembang di Indonesia, salah satunya ialah Es Teler 77 Juara Indonesia. ${ }^{5}$ KFC, Mc Donald's, Burger King dan Wendys merupakan waralaba atau franchise asal Amerika Serikat.

1 David Hess, "The lowa Franchise Act: Toward Protecting Reasonable Expectation of Franchisees and Franchisors" lowa Law Review, Vol.80, Januari 1995, hlm.920

2 Franchisor: One who grant a franchise, Bryan A. Garner, Black's Law Dictionary, Eight Edition, United States: Thomson West, 2004.

3 Franchisee: One who is granted a franchise, Ibid.

4 Bill Nickels, Jim Mc Hugh and Susan Mc Hugh Terjemahan Elevita Yulianti dan Dina Angelica, Pengantar Bisnis, Jakarta: Salemba Empat, 2009, hlm.175.

5 Adrian Sutedi, Hukum Waralaba, Jakarta: Ghalia Indonesia,, 2008, hlm.19. 
Menurut Amir Karamoy, waralaba pada hakekatnya merupakan sebuah konsep pemasaran dalam rangka memperluas jaringan usaha secara cepat. Waralaba bukanlah sebuah alternatif melainkan salah satu cara yang sama kuatnya, sama strategisnya dengan cara konvensional dalam mengembangkan usaha. Bahkan sistem waralaba dianggap memiliki banyak kelebihan terutama menyangkut pendanaan, sumber daya manusia dan manajemen, kecuali kerelaan pemilik merek untuk berbagi dengan pihak lain. Waralaba juga dikenal sebagai jalur distribusi yang sangat efektif untuk mendekatkan produk kepada konsumennya melalui tangan-tangan penerima waralaba. ${ }^{6}$ Pada awalnya waralaba dikenal sebagai cara pemasaran dan dikenal dengan waralaba produk, sekarang berkembang menjadi suatu konsep bisnis dengan istilah waralaba format bisnis.

\section{Waralaba Berdasarkan Sistem Syariah}

Waralaba atau franchise telah mengalami pertumbuhan yang luar biasa di Indonesia. Menurut Data dari Perhimpunan Waralaba dan Lisensi Indonesia (WALI), jumlah waralaba di Indonesia tahun 2010 baik lokal maupun asing berjumlah 1.198 waralaba. Pertumbuhan waralaba yang luar biasa ini didorong oleh beberapa hal diantaranya krisis keuangan global yang masih terasa hingga sekarang sehingga perbankan masih ketat dalam penyaluran kredit, di sisi lain banyaknya perusahaan-perusahaan yang bangkrut telah memberhentikan banyak profesional dengan pesangon yang besar. Para profesional tersebut terus mencari peluang bisnis salah satunya melalui peluang bisnis waralaba. Oleh karena itu, banyak dari para profesional yang tadinya bekerja pada perusahaan-perusahaan beralih profesi menjadi pengusaha franchise. Kemajuan pesat ini tidak hanya terjadi para franchise lokal tetapi juga franchise asing. Pertumbuhan franchise asing sebesar $28 \%$ dan franchise lokal sebesar $72 \%$. Angka ini menunjukan bahwa perkembangan waralaba lokal jauh lebih pesat dibandingkan dengan waralaba asing.

Di Indonesia saat ini mulai berkembang waralaba berdasarkan prinsip syariah diantaranya adalah Madani Mart Minimarket (bergerak di usaha ritel), Sejahtera Bersama Mart (bergerak di usaha ritel), Umiku Crepes and Burger (bergerak dibidang crepes dan burger), Chiken Room (bergerak dibidang makanan siap saji dengan berbahan baku utama ayam), Pijat Syariah Tomura (bergerak dibidang usaha pijat dan spa), dan Simply Hommy Guest House (bergerak dibidang guest house).

6 Amir Karamoy, "waralaba Indonesia." ‘http://www.majalahfranchise.com>[14/12/ 2010]. 
Waralaba-waralaba tersebut mengklaim menggunakan prisip-prinsip syariah yang bersumber dari Al Quran, Hadits dan ljtihad. Syariah, di sisi kebahasaan terdapat beberapa pengertian, diantaranya ialah jalan yang harus diikuti. Istilah syari'ah mempunyai akar yang kuat di dalam Al-Quran (QS Al-Maidah (5):48), (QS.Asy-Syuura (42):13) seperti penjelasan firman Allah yang artinya Kemudian kami jadikan kamu berada di atas syariat (peraturan) dari urusan (agama itu), maka ikutilah syariat itu dan janganlah kamu ikuti hawa nafsu orang-orang yang tidak mengetahui (QS.AI Jaatsiyah (45):18). Berdasarkan kutipan ayat tersebut, maka istilah Hukum Syariah dapat diartikan sebagai ketetapan Allah SWT yang harus diikuti oleh hambaNya. ${ }^{7}$

Fiqih adalah ilmu hukum yang kadang dapat digunakan sebagai sinonim Syariah. Akan tetapi keduanya berbeda, karena syariah erat kaitannya dengan wahyu, pengetahuan yang hanya dapat di dapat dari Al Quran dan Sunnah. Sebaliknya, fiqih sebagai besar dikembangkan oleh para fuquha dan terdiri dari aturan-aturan yang terutama didasarkan pada penalaran manusia dan ijtihad. ${ }^{8}$

Syariah berasal dari Al Quran dan ia terdiri dari ketentuan-ketentuan spesifik serta prinsip-prinsip umum yang memiliki makna hukum dan moral. ${ }^{9}$ Aturan-aturan yang jelas dan spesifik dalam Al Quran dan Sunnah merupakan inti dari Syariah. ${ }^{10}$ Secara umum syariah merujuk pada perintah, larangan, panduan dan prinsip dari Tuhan untuk perilaku manusia di dunia ini dan keselamatannya di akhirat. ${ }^{11}$

Ada dua sumber syariah yang diturunkan yaitu Al Quran dan Sunnah. Sumber lain adalah penalaran manusia dan ijtihad. Al Quran bukanlah dokumen hukum atau konstitusi, karena materi hukum hanya merupakan bagian kecil dari Al Quran. Hukum pun terdiri dari Hukum Perkawinan, Hukum Waris, Hukum Perjanjian, Hukum Pidana, Prinsip Disiplin, Hukum Perang, Prinsip Musyawarah, Hukum Antar Bangsa-Bangsa. ${ }^{22}$ Hukum dalam

7 Burhanuddin S, Hukum Kontrak Syariah, Yogyakarta: BPPE, 2009,hlm.4

8 Mohammad Hashim Kamali, Terjemahan Syariah Law, An Introduction, Membumikan Syariah, Jakarta: Mizan, 2008, hlm.21.

9 Mohammad Hashim Kamali, Membumikan Syariah, Pergulatan Mengaktualkan Islam, diterjemahkan dari Syariah Law, An Introduction oleh Miki Salman, Bandung: Mizan Publika, 2013, hlm.51.

10 Ibid.

11 Idem, hlm.19.

12 Departemen Agama Republik Indonesia, Al Quran dan Terjemahnya, Semarang: Kumudasmoro Grafindo, 1994, hlm.100-101. 
Islam ada lima yaitu:13

1. Wajib, yaitu perintah yang mesti dikerjakan. Jika perintah tersebut dipatuhi (dikerjakan), maka yang mengerjakannya mendapat pahala; jika tidak dikerjakan maka ia berdosa.

2. Sunat, yaitu anjuran. Jika dikerjakan dapat pahala, jika tidak dikerjakan tidak berdosa.

3. Haram, yaitu larangan keras. Kalau dikerjakan berdosa jika tidak dikerjakan (ditinggalkan) mendapat pahala.

4. Makruh, yaitu larangan yang tidak keras. Kalau dilanggar tidak dihukum (tidak berdosa), dan jika ditinggalkan diberi pahala.

5. Mubah, yaitu sesuatu yang boleh dikerjakan dan boleh pula ditinggalkan. Kalau dikerjakan, tidak berpahala dan tidak pula berdosa; kalau ditinggalkan, tidak berpahala dan tidak pula berdosa.

Syariah terdiri dari ibadah dan muamalah. Ibadah meliputi bersuci, sholat, puasa, zakat dan haji. Sedangkan muamalah terdiri dari sistem keluarga, sistem pembagian harta pusaka, Hukum Perdata, Hukum Pidana, Pengembangan Ilmu Pengetahuan dan Teknologi.14

Muamalah dalam arti luas adalah segala peraturan yang diciptakan Allah untuk mengatur hubungan manusia dengan manusia dalam hidup dan kehidupan. ${ }^{15}$ Muamalah dalam arti sempit adalah aturan-aturan Allah yang wajib ditaati yang mengantur hubungan manusia dengan manusia dalam kaitannya dengan cara memperoleh dan mengembangkan harta benda. ${ }^{16}$ Persamaan pengertian muamalah dalam arti sempit dan arti luas yaitu samasama merupakan aturan Allah yang mengatur hubungan manusia dengan manusia dalam kaitan dengan pengelolaan harta.

Waralaba merupakan kerjasama pengelolaan harta yaitu harta atau benda bergerak tidak berwujud yang tidak lain adalah kumpulan dari hak kekayaan intelektual. Waralaba berkembang tidak hanya yang konvensional seperti KFC, Mc Donald, Es Teler 77 Juara Indonesia, Indomart, LP3I. Berkembang juga waralaba berdasarkan sistem atau konsep syariah.

13 Sulaiman Rasjid, Fiqh Islam, Bandung: Sinar Baru Algensindo, 2010, hlm.1.

14 Wahyudin, (et.al), Pendidikan Agama Islam, Jakarta: Grasindo, 2012, hlm.20

15 Abdul Madjid, Pokok-Pokok Fiqh Muamalah dan Hukum Kebendaan Dalam Islam, Bandung: IAIN Sunan Gunung Djati, 1986, hlm.1.

16 Hendi Suhendi, Fiqh Muamalah, Jakarta: RajaGrafindo Persada, 2011, hlm.3. 


\section{Penerapan Prinsip Syariah Dalam Praktik Perjanjian Waralaba dan Pengawasannya}

Syariah merujuk pada perintah, larangan, panduan dan prinsip dari Tuhan untuk perilaku manusia di dunia dan keselamatannya di Akhirat. ${ }^{17}$ Sumber, maksud dan nilai-nilai syariah adalah bagian dari Islam. Syariah sepenuhnya dari agama, atau dari kepercayaan dan nilai-nilai dasar Islam.Secara legalistik banyak yang mengambarkan syariah sebagai perintah-perintah Tuhan untuk kegiatan manusia. ${ }^{18}$

Syariah memiliki prinsip-prinsip yang bersumber dari Al Qur'an dan Hadist. Salim Umar ${ }^{19}$ menyatakan ada tiga macam prinsip-prinsip syariah yaitu terhindar dari maysir, gharar dan riba. Maysir adalah semua bentuk perpindahan harta ataupun barang dari satu pihak kepada pihak lain tanpa melalui jalur akad yang telah digariskan syariah, namun perpindahan itu terjadi melalui suatu permainan. Gharar adalah sesuatu yang tidak jelas dan tidak dapat dijamin atau dipastikan kewujudannya secara matematis dan rasional baik itu menyangkut barang, harga ataupun waktu pembayaran uang / penyerahan barang. Riba merupakan pertukaran sesama barang ribawi dengan kadar yang berbeda. Perbedaan itulah yang disebut riba.

Waralaba merupakan pengembangan dari bentuk syirkah bila dilihat dari sudut bentuk perjanjian. Hal ini disebabkan oleh dengan adanya perjanjian waralaba, maka secara otomatis antara pemberi waralaba dan penerima waralaba terbentuk hubungan kerjasama untuk waktu tertentu (sesuai perjanjian). Kerjasama tersebut dimaksudkan untuk memperoleh keuntungan bagi kedua belah pihak. Prinsip keterbukaan dan kehati-hatian diterapkan dalam waralaba, hal ini sesuai dengan prinsip transaksi dalam Islam yaitu terhindar gharar (ketidak jelasan). Bisnis waralaba ini pun mempunyai manfaat yang cukup berperan dalam meningkatkan pengembangan usaha mikro, kecil dan menengah.

Suatu waralaba adalah bentuk perjanjian kerja sama (syirkah) yang isinya pemberi waralaba memberikan hak dan wewenang khusus kepada pihak penerima waralaba. Waralaba merupakan suatu perjanjian timbal balik, karena pemberi waralaba maupun penerima waralaba. Keduanya berkewajiban untuk memenuhi prestasi tertentu sebagaimana diperjanjikan.

17 Mohammad Hashim Kamali, Membumikan Syariah, Pergulatan Mengaktualkan Islam, Terjemahan Syariah Law, An Introduction, Mizan, 2013, hlm.19.

18 Ibid.

19 Salim Umar, Ketua Bidang Fatwa Majelis Ulama Indonesia Propinsi Jawa Barat dan Guru Besar Universtias Islam Negeri Sunan Gunung Jati Bandung. 
Meski demikian mengingat perjanjian waralaba biasanya telah disiapkan terlebih dahulu oleh pemberi waralaba sehingga masuk katagori perjanjian baku. Menurut Purwahid Patrik, perjanjian baku secara sederhana didefinisikan sebagai suatu perjanjian yang didalamnya telah terdapat syaratsyarat tertentu yang dibuat oleh salah satu pihak..$^{20}$ Syarat-syarat tertentu dalam perjanjian waralaba ditentukan oleh pemberi waralaba.

Terdapat persamaan dan perbedaan antara waralaba dengan syirkah. Persamaannya adalah pertama, waralaba adalah kerjasama (syirkah) yang saling menguntungkan, berarti waralaba memang dapat dikatakan kategori dari syirkah dalam hukum Islam. Kedua, terdapat prestasi bagi penerima waralaba, hal ini sama dengan syirkah mudharabah muqayyadah. Ketiga, terdapat barang, jasa dan tenaga memenuhi salah satu syarat syirkah. Keempat, terdapat 2 orang atau lebih yang bertransaksi, sepakat, hal tertentu, ditulis (dicatat) dan oleh sebab tertentu sesuai dengan syarat akad, khususnya syirkah mudharabah.

Terdapat perbedaan antara waralaba dengan mudharabah. Adapun perbedaannya terletak pada , pertama dalam syirkah mudharabah, modal harus berupa uang, tidak boleh barang sedangkan dalam waralaba modal dibantu oleh pemberi waralaba baik urang, barang, tenaga professional. Kedua dalam waralaba terdapat kerjasama dalam bidang hak kekayaan intelektual yaitu hak cipta, merek dagang, paten, desain industri, rahasia dagang. Pada hukum Islam hal tersebut syirkah amlak (hak milik). Ketiga, tidak boleh kerja sama dalam hal berjualan yang haram, sedangkan dalam hukum positif tidak terdapat pembatasan terhadap hal tersebut.

Waralaba dapat dikatagorikan ke dalam perkembangan syirkah mudharabah jenis muqayadah di mana pihak penerima waralaba terikat pada aturan-aturan yang diberikan oleh pemberi waralaba atau dalam syirkah mudharabah disebut dengan pemberi modal. Perkembangannya adalah masuknya hak milik atau Hak Kekayaan Intelektual ke dalam transaksi, mungkin hal ini dapat dimasukan syirkah ikhtiyariyah secara garis besar. Akan tetapi, yang menjadi catatan meskipun waralaba diperbolehkan dengan alas an perkembangan syirkah, dalam waralaba harus mengikuti prinsip dasar transaksi dalam hukum Islam dan barang yang dibuat yang dibuat untuk transaksi tidak bertentangan dengan syara' atau barang-barang/hewan yang diharamkan untuk dperjualbelikan dalam Islam.

20 Purwahid Patrik, “Masalah Standard Kontrak Dalam Perjanjian Kredit”, Makalah Seminar yang diselenggarakan oleh Ikatan Advokat Indonesia di Surabaya tanggal 11 Desember 1993, hlm.1. 
Prinsip syariah yang diterapkan perlu diawasi jangan sampai mengatasmakansyariahnamunsebenarnyamasihkonvensional.Pengawasan merupakan hal yang utama dalam suatu menajemen, pengawasan menjadi indikator apakah rencana sudah sesuai dengan yang dijalankan. Begitu juga dengan penerapan syariah dalam setiap bisnis. Harus dapat dipastikan bahwa syariah yang diterapkan benar-benar syariah yang sesungguhnya yang bersumber dari Al Quran, Hadits dan ljtihad para ulama terkemuka. Di Indonesia, peran pengawasan terhadap penerapan prinsip syariah ada pada Majelis Ulama Indonesia.

Majelis Ulama Indonesia (MUI) adalah Lembaga Swadaya Masyarakat yang mewadahi ulama, zu'ama, dan cendikiawan Islam di Indonesia untuk membimbing, membina dan mengayomi kaum muslimin di seluruh Indonesia. Majelis Ulama Indonesia berdiri pada tanggal, 7 Rajab 1395 Hijriah, bertepatan dengan tanggal 26 Juli 1975 di Jakarta, Indonesia. ${ }^{21}$

MUI berdiri sebagai hasil dari pertemuan atau musyawarah para ulama, cendekiawan dan zu'ama yang datang dari berbagai penjuru tanah air, antara lain meliputi dua puluh enam orang ulama yang mewakili 26 Provinsi di Indonesia pada masa itu, 10 orang ulama yang merupakan unsur dari ormas-ormas Islam tingkat pusat, yaitu, NU, Muhammadiyah, Syarikat Islam, Perti. AI Washliyah, Math'laul Anwar, GUPPI, PTDI, DMI dan Al Ittihadiyyah, 4 orang ulama dari Dinas Rohani Islam, Angkatan Darat, Angkatan Udara, Angkatan Laut dan POLRI serta 13 orang tokoh/cendekiawan yang merupakan tokoh perorangan. Dari musyawarah tersebut, dihasilkan adalah sebuah kesepakatan untuk membentuk wadah tempat bermusyawarahnya para ulama. zuama dan cendekiawan muslim, yang tertuang dalam sebuah "Piagam Berdirinya MUI," yang ditandatangani oleh seluruh peserta musyawarah yang kemudian disebut Musyawarah Nasional Ulama. ${ }^{22}$

Momentum berdirinya MUI bertepatan ketika bangsa Indonesia tengah berada pada fase kebangkitan kembali, setelah 30 tahun merdeka, di mana energi bangsa telah banyak terserap dalam perjuangan politik kelompok dan kurang peduli terhadap masalah kesejahteraan rohani umat. Dalam perjalanannya, selama dua puluh lima tahun, Majelis Ulama Indonesia sebagai wadah musyawarah para ulama, zu'ama dan cendekiawan muslim berusaha untuk:23

21 www.mui.or.id.

22 Ibid.

23 Ibid. 
1. memberikan bimbingan dan tuntunan kepada umat Islam Indonesia dalam mewujudkan kehidupan beragama dan bermasyarakat yang diridhoi Allah Subhanahu wa Ta'ala;

2. memberikan nasihat dan fatwa mengenai masalah keagamaan dan kemasyarakatan kepada Pemerintah dan masyarakat, meningkatkan kegiatan bagi terwujudnya ukhwah Islamiyah dan kerukunan antar-umat beragama dalam memantapkan persatuan dan kesatuan bangsa serta;

3. menjadi penghubung antara ulama dan umaro (pemerintah) dan penterjemah timbal balik antara umat dan pemerintah guna mensukseskan pembangunan nasional;

4. meningkatkan hubungan serta kerjasama antar organisasi, lembaga Islam dan cendekiawan muslimin dalam memberikan bimbingan dan tuntunankepada masyarakat khususnyaumat Islam denganmengadakan konsultasi dan informasi secara timbal balik.

Pada khittah pengabdian Majelis Ulama Indonesia telah dirumuskan lima fungsi dan peran utama MUI yaitu: ${ }^{24}$

1. Sebagai pewaris tugas-tugas para Nabi (Warasatul Anbiya)

2. Sebagai pemberi fatwa (mufti)

3. Sebagai pembimbing dan pelayan umat (Ri'ayat wa khadim al ummah)

4. Sebagai gerakan Islah wa al Tajdid

5. Sebagai penegak amar ma'ruf nahi munkar

Sebagai organisasi yang dilahirkan oleh para ulama, zuama dan cendekiawan muslim serta tumbuh berkembang di kalangan umat Islam, Majelis Ulama Indonesia adalah gerakan masyarakat. Dalam hal ini, Majelis Ulama Indonesia tidak berbeda dengan organisasi-organisasi kemasyarakatan lain di kalangan umat Islam, yang memiliki keberadaan otonom dan menjunjung tinggi semangat kemandirian. Semangat ini ditampilkan dalam kemandirian dalam arti tidak tergantung dan terpengaruh kepada pihak-pihak lain di luar dirinya dalam mengeluarkan pandangan, pikiran, sikap dan mengambil keputusan atas nama organisasi. ${ }^{25}$

Majelis Ulama Indonesia tidak bermaksud dan tidak dimaksudkan untuk menjadi organisasi supra-struktur yang membawahi organisasi-organisasi kemasyarakatan tersebut, dan apalagi memposisikan dirinya sebagai wadah tunggal yang mewakili kemajemukan dan keragaman umat Islam. Majelis 
Ulama Indonesia, sesuai niat kelahirannya, adalah wadah silaturrahmi ulama, zuama dan cendekiawan Muslim dari berbagai kelompok di kalangan umat Islam.

Kemandirian Majelis Ulama Indonesia tidak berarti menghalanginya untuk menjalin hubungan dan kerjasama dengan pihak-pihak lain baik dari dalam negeri maupun luar negeri, selama dijalankan atas dasar saling menghargai posisi masing-masing serta tidak menyimpang dari visi, misi dan fungsi Majelis Ulama Indonesia. Hubungan dan kerjasama itu menunjukkan kesadaran Majelis Ulama Indonesia bahwa organisasi ini hidup dalam tatanan kehidupan bangsa yang sangat beragam, dan menjadi bagian utuh dari tatanan tersebut yang harus hidup berdampingan dan bekerjasama antarkomponen bangsa untuk kebaikan dan kemajuan bangsa. Sikap Majelis Ulama Indonesia ini menjadi salah satu ikhtiar mewujudkan Islam sebagai rahmatan lil alamin (Rahmat bagi Seluruh Alam).

Dewan Syariah Nasional (DSN) merupakan bagian dari Majelis Ulama Indonesia (MUI) yang bertugas menumbuh kembangkan penerapan nilainilai syariah dalam kegiatan perekonomian pada umumnya dan sektor keuangan pada khususnya, termasuk usaha bank, asuransi dan reksadana. Anggota DSN terdiri dari para ulama, praktisi dan pakar dalam bidang-bidang yang terkait dengan perekonomian dan syariah muamalah. Anggota DSN ditunjuk dan diangkat oleh MUI untuk masa bakti 4 tahun. Menurut MUI (SK MUI No Kep.754/II/1999) ada empat tugas pokok DSN:

a. Menumbuh kembangkan penerapan nilai-nilai syariah dalam kegiatan perekonomian,

b. Mengeluarkan fatwa atas jenis-jenis kegiatan keuangan,

c. Mengeluarkan fatwa atas produk keuangan syariah, dan

d. Mengawasi penerapan fatwa yang telah dikeluarkan.

DSN merupakan satu-satunya badan yang mempunyai kewenangan mengeluarkan fatwa atas jenis-jenis kegiatan, produk dan jasa keuangan syariah serta mengawasi penerapan fatwa dimaksud oleh lembaga-lembaga keuangan syariah di Indonesia. Di samping itu DSN juga mempunyai kewenangan untuk :

a. memberikan atau mencabut rekomendasi nama-nama yang akan duduk sebagai anggota DPS pada satu lembaga keuangan syariah.

b. Mengeluarkan fatwa yang mengikat DPS di masing-masing lembaga keuangan syariah dan menjadi dasar tindakan hukum fihak terkait. 
c. Mengeluarkan fatwa yang menjadi landasan bagi ketentuan yang dikeluarkan oleh instansi yang berwenang, seperti Bank Indonesia dan BAPEPAM.

d. Memberikan peringatan kepada lembaga keuangan syariah untuk menghentikan penyimpangan dari fatwa yang telah dikeluarkan oleh DSN.

e. Mengusulkan kepada pihak yang berwenang untuk mengambil tindakan apabila peringatan tidak diindahkan

Tugas, Wewenang dan Tanggungjawab Dewan Pengawas Syariah(DPS) antara lain;

a. Memastikan dan mengawasi kesesuaian kegiatan operasional bisnis terhadap fatwa yang telah ditetapkan oleh DSN-MUI.

b. Menilai aspek syariah terhadap pedoman operasional beserta produk yang dikeluarkan pelaku bisnis

c. Memberikan opini dari aspek syariah terhadap pelaksanaan operasional bisnis syariah secara keseluruhan dan laporan publikasi bisnis

d. Mengkaji produk dan jasa baru yang belum ada fatwa untuk dimintakan fatwa kepada DSN-MUI.

e. Menyampaikan hasil pengawasan syariah sekurang-kurangnya setiap 6 bulan kepada Direksi, Komisaris, DSN-MUI.

Anwar Ibrahim menguraikan bahwa Dewan Syariah Nasional membentuk Dewan Pengawas Syariah guna mengawasi penerapan prinsip-prinsip syariah dalam bank dan pembiayaan syariah secara independen..$^{26}$ Dewan Syariah Nasional merupakan badan di bawah Majelis Ulama Indonesia. Dewan Pengawas Syariah (DPS) adalah badan independen yang ditempatkan oleh Dewan Syariah Nasional (DSN) pada perbankan dan lembaga keuangan syariah. Anggota DPS harus terdiri dari para pakar di bidang syariah muamalah yang juga memiliki pengetahuan di bidang ekonomi perbankan. ${ }^{27}$

Pada pelaksanaan tugas sehari-hari, DPS wajib mengikuti fatwa DSN yang merupakan otoritas tertinggi dalam mengeluarkan fatwa mengenai kesesuaian produk dan jasa bank dengan ketentuan dan prinsip syariah. Tugas utama DPS adalah mengawasi kegiatan usaha bank agar tidak menyimpang dari ketentuan dan prisnip syariah yang telah difatwakan oleh DSN. ${ }^{28}$

26 Anwar Ibrahim, Ketua Dewan Syariah Nasional Majelis Ulama Indonesia.

27 Agustianto,"Optimalisasi Peran Dewan Pengawas Syariah, “www.agustiantocentre.com. 9 Mei 2011

28 lbid. 
Selain Majelis Ulama Indonesia, peran pengawasan juga perlu dilakukan oleh Pemerintah sebagai regulator. Pemerintah dalam hal ini Kementrian Perdagangan mendorong agar usaha waralaba termasuk waralaba berdasarkan system syariah dapat didaftarkan. Pendaftaran ini merupakan upaya untuk adanya data terkait dengan usaha waralaba yang nantinya bermanfaat untuk dilakukan upaya pemberdayaan dari Pemerintah. ${ }^{29}$ Sampai saat ini masih sedikit kesadaran dari pemilik usaha waralaba atau penerima waralaba yang mendaftarkan usaha waralabanya ke Depertemen Perdagangan, dan tentu saja hal ini menyulitkan bagi pemerintah dalam hal ini Kementrian Perdagangan melakukan pemberdayaan.

Kementerian Perdagangan merasa harus melindungi pelaku usaha yang terkait dengan waralaba yang pada umumnya untuk penerima waralaba adalahpelakuusahamikro, kecildanmenengah(UMKM). MakaituKementrian Perdagangan merevisi Permendag No. 31/MDAG/PER/8/2008 dan kebijakan waralaba yang mengatur pembatasan gerai company owned. Peraturan itu diganti dengan Peraturan Menteri Perdagangan (Permendag) No. 07/MDAG/PER/2/2013 tentang Pengembangan Kemitraan dalam Waralaba untuk Jenis Usaha Makanan dan Minuman. Permendag ini mengatur kepemilikan company owned outlet waralaba untuk Kafetaria, Restoran, Rumah Makan, Bar/Rumah Minum sejumlah 250 gerai dan Minimarket sejumlah 150 gerai. ${ }^{30}$

Selain itu, pengusaha waralaba berkewajiban penggunaan bahan baku, peralatan usaha serta menjual barang dagangan paling sedikit 80 persen barang dan/atau jasa produksi dalam negeri. Kebijakan ini untuk meningkatkan daya saing lokal dengan waralaba internasional. Sampai akhir 2013, Permendag itu membuat waralaba lokal di tingkat UKM bergairah. Buktinya jumlah pengusaha waralaba lokal naik. Jumah pendampingan Waralaba bagi UKM pun meningkat hingga rata-rata 20 persen. Itu berdasarkan persentasi dari 2012 ke 2013.

Aturan itu agar UKM bisa bersaing di pasar tunggal ASEAN 2015. Sebab jika aturan ini tidak dikeluarkan maka UKM akan berada pada posisi yang cukup berbahaya jika tak segera diatur waralaba makanan dan minuman. Melalui kebijakan waralaba tersebut, pemerintah berusaha agar waralaba nasional tetap eksis ditengah membanjirnya produk luar. Pemerintah juga dapat mempromosikan produk lokal dengan menetapkan kewajiban

29 Yosier Thalita, Praktisi Manajemen dan Prosedur Ekspor Impor Direktora Bina Usaha Perdagangan Derektorat Jenderal Perdagangan Dalam Negeri Kementrian Perdagangan Republik Indonesia, Jakarta 2013 
penggunaan bahan baku, peralatan yang digunakan maupun barang yang dijual. ${ }^{31}$

Pemerintah melalui Kementrian Perdagangan harusnya proaktif dalam pembinaan waralaba khususnya waralaba lokal baik yang bersifat konvensional maupun yang berdasarkan system syariah. Pemerintah pula melalui Kementrian Hukum dan Perudang-Undangan khususnya Direktorat Jenderal Hak Kekayaan Intelektual mendorong dan memberikan insentif supaya hak kekayaan intelektual yang merupakan inti dari waralaba dapat terdaftar, karena salah syarat dalam menjalankan usaha waralaba adalah memiliki hak kekayaan intelektual yang terdaftar.

\section{Penutup}

Banyaknya waralaba yang mengklaim menerapkan prinsip syariah tentu membutuhkan peran pengawas sehingga prinsip syariah yang diterapkan benar-benar prinsip syariah yang bersumber dari AI Quran, Hadist dan ljtihad. Selama ini usaha-usaha yang mengklaim menggunakan prinsip syariah, pengawasannya dilakukan oleh Majelis Ulama Indonesia melalui salah satu lembaganya yaitu Dewan Pengawas Syariah. Begitu juga dengan usaha waralaba yang berdasarkan system syariah, perlu ada pengawasan dari Dewan Pengawas Syariah sehingga prinsip-prinsip syariah yang diterapkan benar-benar prinsip syariah sebagaimana yang ada dalam tuntutan AI Quran, Hadits dan ljtihad.

\section{DAFTAR PUSTAKA}

\section{Buku:}

Abdulkadir Muhammad, Hukum Perusahaan Indonesia, Bandung: Citra Aditya Bakti, 2003..

Abdul Madjid, Pokok-Pokok Figh Muamalah dan Hukum Kebendaan Dalam Islam, Bandung: IAIN Sunan Gunung Djati, 1986.

Adrian Sutedi, Hukum Waralaba, Jakarta: Ghalia Indonesia,, 2008.

Bill Nickels, Jim Mc Hugh and Susan Mc Hugh Terjemahan Elevita Yulianti dan Dina Angelica, Pengantar Bisnis, Jakarta: Salemba Empat, 2009.

Burhanuddin S, Hukum Kontrak Syariah, Yogyakarta: BPPE, 2009

Bryan A. Garner, Black's Law Dictionary, Eight Edition, United States: Thomson West, 2004. 
Departemen Agama Republik Indonesia, Al Quran dan Terjemahnya, Semarang: Kumudasmoro Grafindo, 1994

Hendi Suhendi, Fiqh Muamalah, Jakarta: RajaGrafindo Persada, 2011.

Mohammad Hashim Kamali, Membumikan Syariah, Pergulatan Mengaktualkan Islam, Terjemahan Syariah Law, An Introduction, Mizan, 2013

Sulaiman Rasjid, Fiqh Islam, Bandung: Sinar Baru Algensindo, 2010.

Wahyudin, (et.al), Pendidikan Agama Islam, Jakarta: Grasindo, 2012.

\section{Jurnal, Artikel dan Makalah:}

M. Muchtar Rivai, "Pengaturan Waralaba di Indonesia: Perspektif Hukum Bisnis”, Jurnal Liquidity, Vol.1 No.2 Juli-Desember 2012.

David Hess, "The lowa Franchise Act: Toward Protecting Reasonable Expectation of Franchisees and Franchisors" lowa Law Review, Vol.80, Januari 1995.

Purwahid Patrik, "Masalah Standard Kontrak Dalam Perjanjian Kredit", Makalah Seminar yang diselenggarakan oleh Ikatan Advokat Indonesia di Surabaya tanggal 11 Desember 1993

\section{Peraturan Perundang-Undangan:}

Undang-Undang No.20 Tahun 2008 Tentang Usaha Mikro, Kecil dan Menengah.

Peraturan Pemerintah No.42 Tahun 2007 Tentang Waralaba

Peraturan Mahkamah Agung No.2 Tahun 2008 Tentang Kompilasi Hukum Ekonomi Syariah

Peraturan Menteri Perdagangan No. 53/M-DAG/PER/8/2012 Tentang Penyelenggaraan Waralaba.

Keputusan Menteri Perindustrian dan Perdagangan Nomor 259/MPP/ Kep/7/1997 Tentang Ketentuan dan Tata Cara Pelaksanaan Pendaftaran Usaha Waralaba.

Peraturan Menteri Perdagangan (Permendag) No. 07/M-DAG/PER/2/2013 tentang Pengembangan Kemitraan dalam Waralaba untuk Jenis Usaha Makanan dan Minuman.

\section{Sumber Elektronik:}

Agustianto, "Optimalisasi Peran Dewan Pengawas Syariah, "www. agustiantocentre.com. 9 Mei 2011 
Amir Karamoy, “waralaba Indonesia.” 〈http://www.majalahfranchise. com $>[14 / 12 / 2010]$.

Herustiati dan victoria Simanungkalit," Waralaba: Bisnis Prospektif Bagi UMKM", <hhtp//www.smecda.com>[12/11/2012].

WALI, "Jumlah Waralaba" swww.detikfinance.coms [27/02/2011].

www.franchise-id.com/franchise-articles.php,[05/02/2011].

www.mui.or.id.

www.simplyhouse.com

www.chikenroom.com.

www.sbmart.co.id.

www.cintaumiku.webs.com

www.tomurapijatsyariah.blogspot.com 